“IŞ, Güç” Endüstri İlişkileri ve İnsan Kaynakları Dergisi

Cilt:7 Sayı:1, Ocak 2005, ISSN: 1303-2860

\title{
YÖNETIM MUHASEBESININ PERFORMANS YÖNETIMI FONKSIYYNUNDA GELDIĞi SON NOKTA:BALANCED SCORECARD (ÖLÇÜM KARTI TEKNIĞI)
}

\author{
SAIT YÜKSEL KAYGUSUZ \\ Yard.Doç.Dr.,Uludağ Üniversitesi, İiBF, İşletme Bölümü
}

\section{ÖZET}

Rekabetçi ortamda faaliyette bulunan işletmeler, ayakta kalabilmenin yollarını bulmalıdırlar. İşletmenin içinde bulunduğu ortamın seçilen ve uygulanan kontrol ve iletişim sistemi üzerinde önemli bir etkisi vardır. Yönetim muhasebesi, faaliyetlerde ve faaliyet sonuçlarının ölçülmesi ve ayrıca ödüllerin belirlenmesinde önemli bir rol oynar. Finansal tabanlı bir performans yönetim sistemi işletmeler için yol gösterici olmayacaktır. Sürekli gelişme için, işletmelere uygun misyon ve stratejinin belirlenmesi ve bu misyon ve stratejileri uygulamak için işletmenin amaçlarını, performans ölçülerini ve zorunlu önceliklerini dikkatli bir şekilde belirlemesi için bu formal yol gösterici sisteme, yöneticiler ihtiyaç duymaktadır. Bu sistem, ölçüm kartı tekniğidir. Ölçüm kartı, işletmenin strateji ve misyonunu dört farklı boyutta operasyonel amaç ve ölçülere aktarmaktadır. Bunlar:"finansal", "müşteri", "içsel süreç" ve "öğrenme ve gelişme" boyutlarıdır. Ölçüm kartı tekniği, kritik performans ölçülerini bünyesinde toplayan bir teknik değildir. Performans ölçüleri işletmenin vizyon, strateji ve amaçlarından elde edilmektedir. Özellikle performans ölçüleri işletmenin stratejisi ile bağlantılı olmalıdır.

Anahtar Kelimeler:Performans ölçümü, Performans yönetim sistemi ve ölçüm kartı tekniği

“İş,Güç”, Endüstri İlişkileri ve İnsan Kaynakları Dergisi Erişim: www.isguc.org 


\section{ABSTRACT}

Organizations that operate in competitive, dynamic and rapidly changing environment must find ways to survival. The type of environment in which the firms operate can have a significant effect on the type of control and communication system chosen and implemented. To find ways to improve performance, firms operating in this kind environment are forced to reevaluate how they do things. The management accounting plays a key role in measuring actions and outcomes and in defining the reward to be received by individuals. A financial orientated performance measurement system will not be a guidance for the firms. A formal guidance system for continuous improvement meant that managers of an organization needeed to carefully specify a mission and strategy for their organization and identify the objectives, performance measures and initiatives necessary to accompolish this overall mission and strategy. This guidance system is balanced scorecard. Balanced scorecard, translates the mission and strategy of an organization in to operational objectives and measures for four different perspectives:"financial", "customer", "internal business process" and "innovation and learning". Balanced scorecard is not a collection of critical performance measures. The performance measures are derived from firm's vision, strategy and objectives. Especially, performance measures must be linked to firm's strategy.

Keywords:Performance measurement, Performance management system and balanced scorecard

\section{GiRiş}

İşletmeler, rekabetçi bir ortamda kıran kırana bir rekabet içindedirler. Üretim ortamında mükemmellik ve işletmeyi başarıı gibi gösteren finansal sonuçlar, rekabetçi koşulların yerine getirilmesi anlamına gelmemektedir. Sonuçların değerlendirilmesi, işletmenin rekabetçi koşullarda gerçekleştirdiği faaliyetleri ne derece etkin yaptığını ortaya koyacaktır. Uygulana gelen finansal tabanlı performans yönetim sisteminde, gerçekleştirilen faaliyetlerin etkinliğinin değerlendirilmesi sonucunda, hatalı ve eksik bilgiler raporlanmaktadır. Yöneticilerin karar verme aşamasında kullandıkları veriler geçmişe dönük olmamalı, işletmeyi geleceğin belirsizliklerine karşı daima hazır tutmalıdır. Performans yönetim sistemleri, rekabetçi ve belirsizliğin hakim olduğu bir ortamda işletmeyi dinamik tutmaya yönelik bir yapıya sahip olmalıdır. Yönetim muhasebesinin önemli bir fonksiyonu olan performans yönetimi, işletme yönetimine finansal ölçüler dışında finansal olmayan ölçülere dayalı performans değerlemesinin yapıldığı, işletme stratejisi ve 
vizyonu ile ilişkili olan, karar vermede kullanılan bir sistem olarak hizmet vermektedir. Bu sistemin kendi içerisinde kullandığı değişik araçlar bulunmaktadır. Yönetim muhasebesinin performans ölçümünde yönetime sunduğu yeni bir araç, "ölçüm kartı tekniği” (balanced scorecard)'dir.

\section{PERFORMANS YÖNETIM SISTEMLERININ DEĞERLENDİRILMESİ}

Rekabetin kıran kırana yaşandığı günümüz koşullarında işletmeler rekabetin gereklerine uyum gösteremezler ve cevap veremezler ise, pazardaki konumlarını çok kolay bir şekilde rakiplerine kaptırabilirler. Rekabetçi ortamın gereklerine cevap veremeyen işletmelerin pazardaki konumları tartışılır duruma gelecektir. İşletmelerin içinde bulunduğu rekabetçi ortamı şekillendiren ve rekabetçi ortama yön veren özellikler:(1)Global boyutta rekabet, (2)Üretim teknolojilerindeki hızlı gelişmeler, (3)illetişim teknolojilerindeki hızlı gelişmeler, (4)Müşteriye odaklanma, (5)Yeni yönetim anlayışları ve (6)Sosyal, politik ve kültürel değişiklikler, şeklinde ifade edilmektedir (Blocher, Chen ve Lin, 2001:9).

İşletmeler, başarının tanımını yapmak için kendi yönetim sistemleri içerisinde bir performans değerleme anlayışı geliştirmişlerdir. Yönetim muhasebesinin temel amacı, yönetim için "karar alma araçları" geliştirmesidir. Yönetim muhasebesi uygulamaları ile işletmenin stratejik amaçları arasında kurulan direkt ilişkide, stok değerleme ve vergilemeye yönelik raporlama fonksiyonlarını üstlenen finansal muhasebe kısıtlayıcı rolünü üstlenmektedir. İşletmelerin bir çoğunda "performansı değerlemek" ve "çalışanları motive etmek" amaçları için halen klasik ölçüler kullanılmaktadır. Klasik ölçülerin bir çoğu işletmelerin performansının değerlendirilmesinde geçerliliğini ve gerekliliğini korumaktadır(Santori ve Anderson, 1987:141). Klasik performans yönetim sisteminin özellikleri ve eksik yönleri aşağıda maddeler halinde belirtilmiştir(Glad ve Becker, 1995:172-173):

- Yönetim ve diğer kullanıcıların tek ve toplamı ifade eden rakamlara yönelmeleri,

- Geçmiş verileri göstermeleri ve gelecekteki performans ile ilgili olmamaları,

- Performans ölçümlerinde ağırlıklı olarak finansal göstergeleri kullanmaları,

- Ölçüm ve raporlama, ortaklara yönelik olarak gerçekleştirildiği için, iş görenler, tedarikçiler, devlet, kredi 
verenler ve endüstri gibi diğer menfaat gruplarını dikkate almamaları,

- Finansal performans ölçüleri, işletme bazında performans kriterleri iken, işletmenin faaliyette bulunduğu endüstri bazında kriterler dikkate alınmamaktadır. İşletmenin değerlendirilmesi için faaliyette bulunduğu endüstrideki işletmeler ile karşılaştırılması gerekir.

- Klasik anlayış, faaliyet gösterilen fiziki ortamda, işletme performansı ve işletme rolünü dikkate almamaktadır.

Klasik sistemin özellik ve eksiklikleri incelendiğinde ortaya şu sonuçlar çıkmaktadır:(1)İşletme stratejisi ve performans ölçüm sistemi arasında uyum yoktur, (2)Klasik performans yönetim sistemleri, yenilik ve değişimlere cevap verememektedir. (3)Yapılan işlerin eksik, yanlış ve gerçeğe uygun olmayan bir şekilde değerlendirilmesi hatalı kararlar verilmesine neden olabilir.(4)Bu durum, işletmenin rekabetçi ortamda varlığını sürdürme çalışmalarını desteklemeyecek ve olumsuz bir son hazırlayacaktır. Eğer, bir işletmenin kısa ve uzun vadeli performans ölçüleri yönetimin temel amaçları ile uyumlu değilse, işletmenin başarılı olma olasılığı düşük demektir (Howell, Brown ve diğ., 1987:49). Bu nedenle, işletmelerin, stratejik amaç ve hedeflerine uyum sağlayan etkin bir performans yönetim sisteminin yapılandırılması gerekmektedir.

\section{PERFORMANS YÖNETIM SISTEMININ YAPILANDIRILMASI}

Performans yönetim sisteminin yapılandırılmasında işletme stratejilerine bağlılık ile, değişen koşullara uyum sağlanmalı ve karar vermede etkin rolü üstlenecek kritik başarı faktörleri ve performans ölçüleri geliştirilmelidir. Etkin bir performans yönetim sisteminin yapılandırılması için pazar koşulları, işletme stratejisi, müşteri beklentileri ve geleceğe ilişkin beklentiler gibi özelliklerin belirleyici etkisini göz önünde tutmak gerekir. Etkin bir performans yönetim sisteminin yapılandırılmasında aşağıda belirtilen süreç izlenmelidir (Glad ve Becker, 1995:174):

1. İşletmenin yaşamı için önemli olan içsel ve dışsal faktörlerin tanımlanması.

2. Kritik başarı faktörlerinin belirlenmesi.

3. Performans ölçülerinin belirlenmesi. 
4. Performans ölçümünün organizasyonun alt basamaklarına yayılması.

Aşağıda bu sürece ilişkin açıklamalar yapılmaktadır.

\section{1.İşletmenin yaşamı için önemli olan içsel ve dışsal} faktörlerin tanımlanması: İşletmenin başarılı bir yaşamı ve uzun dönemli gelişimi için önemli olan içsel ve dışsal faktörlerin tanımlanması gerekir. Bu tanımlama, (1)iş̧letmelerin zayıf ve güçlü yanlarının belirlenmesi, (2)Fırsat ve tehditlerin değerlendirilmesi ve (3)Bu konulara ilişkin stratejilerin belirlenmesine yönelik çalışmaların sonucunda yapılır.

2.Kritik başarı faktörlerinin belirlenmesi: Bir işletmenin başarısı için gerekli olan başarı faktörlerinin tanımlanması, stratejilerin formülasyonu ve uygun performans ölçülerinin belirlenmesi için birincil derecede önemlidir. Kritik başarı faktörlerinin seçiminde aşağıda belirtilen esasların dikkate alınması gerekir (Keegan, Eiler ve Jones, 1989:45-49):

- Kritik başarı faktörleri, işletmenin stratejisine göre oluşturulmalıdır.

- Kritik başarı faktörleri, işletmenin faaliyetleri ve stratejik planları arasında bağ oluşturmalıdır.

- Kritik başarı faktörleri, işletmedeki organizasyonel basamaklar için de aynı anlamı ifade etmelidir.

- Kritik başarı faktörleri, işletmenin iç ve dış çevresindeki faaliyetleri de dikkate almalıdır.

- Kritik başarı faktörleri, verilecek kararlar için yeterli olmalı ve kullanıcılar için zamanında hazır olmalıdır.

Işletmelerin belirli dönemlerde gerçekleştirdiği faaliyetlerinin değerlemesinde en çok kullanılan kritik başarı faktörleri:(1)Müşteri tatmini, (2)Kalite, (3)Maliyet, (4)Karlılık ve (5)Esneklik olarak sıralanmaktadır (Smith, 1995:178-182). Ayrıca Gallup tarafından yapılan bir araştırmada en çok kullanılan kritik başarı faktörü sorusuna verilen cevapta şu sıralama ortaya çıkmıştır:(1)Müşteri hizmetleri, (2)Mamul/hizmet kalitesi, (3)Operasyonel etkinlik, (3)ỉletişim ve bilgi teknolojisi, (4)Esneklik ve uyum sağlayabilme, (5)Yenilik, (6)Pazara girme hızı ve (7)Diğer faktörler (Blocher, Chen, Cokıns ve Lin, 2005:37). Bu kritik başarı faktörlerinden müşteri hizmetleri, pazara girme hızı ve yenilik, farklılaştırma stratejisi ile ilgili iken;operasyonel 
etkinlik, maliyet liderliği stratejisi ile ilgilidir. Tüm ölçülerin bir kritik başarı faktörü ile ilişkilendirilmesi gerekmektedir. Bir performans ölçüsü, kritik başarı faktörü ile ilişkilendirilemez ise, ifade edilemeyecektir ve işletmenin stratejik amaçlarını da desteklemeyecektir. Tüm performans ölçülerinin üretim süreci ile ilişkilendirilmesi gerekir. Üretim süreci ile bağlantılı olmayan bir ölçü ifade edilemeyecektir ve kontrol edilemeyecektir (Beischel ve Smith, 1991:26)

3.Performans ölçülerinin belirlenmesi: Performans ölçüleri, yapılan faaliyetlerin sonucunu yansıtan bir göstergedir. İşletmenin ana amaçları tanımlandığında, değerlendirildiğinde ve stratejik plandaki öneme göre sınıflandırıldığında performans ölçüleri belirlenmelidir.Bu ölçüler, işletmenin tüm önemli faaliyetlerinde maliyet yönünden etkin olma ve zamanlı veri sağlanması konularında hassas olmalı, kolay uygulanmalı ve her düzeydeki personel tarafından kabul edilmelidir (Berliner ve Brimson, 1988:161).

\section{Performans ölçümünün organizasyonun alt basamaklarına} yayılması: Performans ölçüm sistemi, sadece üst yönetim tarafından kullanılacak bir sistem değildir. Etkin olarak işleyecek bir performans yönetim sistemi oluşturan işletmelerin rekabetçi pazardaki değişikliklere anında cevap verebilme esnekliğini yakalayacağı bir gerçektir. Amaç, sadece sistemin kurulması değil, değişen ortama uyum sağlayacak şekilde yenilenmesidir (McNair, Lynch ve Cross, 1990:29). Performans ölçümlerinin kullanılığı basamaklar;(1)Pazar düzeyi, (2)ỉşletme düzeyi, (3)Tesis düzeyi ve (4)Hat düzeyi olarak sıralandırılmaktadır (Berliner ve Brimson, 1988:161-163). Performans ölçümünde başarının temeli, her basamak arasında bağlantı kurulması ve bu bağlantıda neden-sonuç ilişkisinin işlerlik kazandırılmasıdır.

Klasik performans ölçüleri, endüstriyel alanda kendinden bekleneni çok iyi şekilde yerine getirmiştir. Ancak bunlar, günümüzde uzmanlık ve rekabet koşullarında yeterli olamamaktadır. Performans yönetim sistemlerinin başarılı bir şekilde yapılandırılması, işletmelerin performans ölçümüne yenilik getirmekle kalmamakta, işletmelerin karşılaşacağı koşullarda da benzer ölçülerin geliştirilmesi, değerlendirilmesi ve uygulanmasında da kullanılmaktadır (Choe, Haddad ve Wilson, 1997:21). Yöneticiler performans ölçümünü, stratejinin önemli bir parçası olarak pek dikkate almamaktadırlar. Bu tip yöneticiler, sadece yeni amaçlar ve süreçleri kontrol etmek için yeni ölçülerin kullanılmasında başarısız olmamakta, eski ölçülerin yeni ortam 
ile ilgili olup olmadıklarına karşı cevap vermede de başarısız olmaktadırlar (Kaplan ve Norton, 1993:134).

İşletmelerin oluşturacakları performans yönetim sistemleri, stratejilerini destekleyici olmalıdır. Bu sistem, müşteri ve iç sürecin performansı ile ilgili olarak finansal ölçüler yanında finansal olmayan ölçüleri de içermelidir. Ayrıca bu sistem, işletme amaçlarını yönetilebilir alt başlıklara dönüştürmek için organizasyonel yapıdaki alt basamaklara dı kapsamalıdır (Epstein ve Manzoni, 1997:28). Oluşturulacak performans yönetim sistemi, işletme stratejisi ile ilişkili olarak, işletmenin iç süreci(değer zinciri), müşteriler ve gelişme faaliyetlerini finansal boyut ile birleştirecek şekilde yapılandırılmalıdır. Basit olarak belirtilen bu amaçları karşılamak üzere Ölçüm Kartı Tekniği geliştirilmiştir.

\section{STRATEJI VE UYGULAMA ARASINDAKI BAĞLANTI:ÖLÇÜM KARTI TEKNIĞi}

Ölçüm kartı tekniği(ÖKT), basit bir ifade ile, stratejinin işler hale getirilmesi ve işletmede, belirlenen strateji doğrultusunda hareket tarzlarını belirlenmesidir. Esas olarak ÖKT, işletmenin kritik başarı faktörleri ile ilgili finansal ve finansal olmayan ölçülerden oluşan bir yapıdır. Yenilik ve değişiklik ifade eden husus, ÖKT'nin temel unsurlarının işletmenin mevcut ve gelecek durumunu göstererek birbirini etkileyecek şekilde yapılandırılmasıdır (Choe, Haddad ve Wilson, 1997:21). Tek tip ölçüler anlaşılır performans hedefleri oluşturamayacak ya da işletmelerin kritik alanlara odaklanmasını engelleyecektir. ÖKT ise, yöneticilere işletme bazında kapsamlı bilgileri hızlı bir şekilde sunan ölçülerin oluşturduğu bir yapıdır. ÖKT, hemen gerçekleştirilen işlemlerin sonuçlarını ifade eden finansal ölçüler içermektedir. ÖKT, müşteri tatmini, işletmenin iç süreci ve işletmenin yenilik ve gelişme faaliyetlerine ilişkin operasyonel ölçüler ile finansal ölçüleri bütünleştirmektedir. Bu tür operasyonel ölçüler, geleceğe ilişkin finansal performansın belirleyicileridir (Kaplan ve Norton, 1992:71)

ÖKT, üst düzey yöneticilere işletme ile ilişkili kapsamlı ve hızlı bilgiler sunan ölçülerden oluşan bir tekniktir. ÖKT, sadece geçmişte gerçekleşen faaliyetlerin kontrolüne dayalı finansal ölçüler ile sınırlanmamakta, operasyonel bazdaki gelişme ve değişmeleri ölçmeye yönelik ölçüleri de bünyesinde barındırmaktadır. Önemli bir nokta, ÖKT'nin bu özelliklerinin işletmenin stratejisi ile ilişkili olmasıdır. 
Stratejinin belirlenmesi ile her şey yolunda gidecek gibi bir beklentiye girmek yanlış olacaktır. Önemli olan, sapmaların belirlenmesi, nedenlerinin araştırıması ve giderilmesine yönelik çözüm önerilerinin geliştirilmesidir. ÖKT, işletmenin vizyon ve stratejisi tarafından belirlenen performans ölçülerinin yer aldığı, performans yönetim sistemine strateji tabanlı bir yaklaşımdır. ÖKT, temel stratejik faaliyetler ve nihai amaç olan finansal değer yaratma arasında bağ oluşturmaktadır (Frigo, 2002:6). Stratejinin, uygulamaya dönüştürülmesindeki fonksiyonu nedeni ile ÖKT, işletmede önemli bir sorumluluk üstlenmiş̧ir. Bu bağlamda ÖKT, sadece stratejinin yönetilmesi değil, stratejinin güçlendirilmesinde de yardımcı olur. ÖKT ile strateji, işletmede her düzeyde çalışanın işi olarak tanımlanmıştır. Strateji ve uygulama arasındaki açık, ÖKT aracııı̆ı ile kapatımıştır. Klasik finansal sistem çalışan, süreç ve yenilik gibi maddi olmayan varlıkların önemini yöneticilere ve çalışanlara aktaramamıştır, ÖKT bunu başarmıştır (Waal, 2003:31).

ÖKT, klasik yönetim sistemlerindeki bir dizi eksikliği de ortaya çıkarmaktadır ki bu, işletmenin uzun dönemli stratejisinin kısa dönemli faaliyetler ile bağlantısıdır (Kaplan ve Norton, 1993:75). İşletmenin uzun dönemli stratejilerinin kısa dönemli faaliyet tarzlarına dönüştürülmesi ile işletme, hem mevcut durumda hem de gelecekteki değişim ve gelişmelere ÖKT aracılığı ile anında cevap verebilecek ve uyum sağlayabilecektir (Constantinides ve Shank, 1994:34-36). Bir çok işletmenin yönetim ve operasyonel kontrol sistemleri finansal ölçüler ve hedefler çerçevesinde yapılandırılmıştır. Bu anlayış, işletmenin uzun dönemli stratejik amaçlarına ulaşmadaki "işletmenin gelişimi" ile çok az iliş̧ki içindedir. Bu nedenle, kısa dönemli finansal ölçülere yönelen işletmeler, stratejilerin geliştirilmesi ve uygulanması arasında açık bırakmaktadır (Kaplan ve Norton, 1993:75). ÖKT, işletmenin performansı ile ilgili kapsamlı bir görüntü sunarak performans yönetimi konusunda yöneticilere yardımcı olmaktadır. Bu görüntüde finansal ölçüler yanında "müşteri sadakati", "kalite", "iş gören bilgisi" ve "süreç gelişimi" gibi finansal olmayan ölçüler de yer almaktadır. Bu faktörlerin yer aldığı bir yapı, yönetimi kısa dönemli ve dar kapsamlı odaklanma yerine uzun dönemli ve daha kapsamlı performans ölçümüne yönlendirmektedir (Silk, 1998:38) 


\section{1.Ölçüm Kartı Tekniği'nin Yapılandırılması}

Stratejik boyutlu bir performans ölçüm sistemi olan ÖKT'nin, belirlenen amaçlar doğrultusunda yapılandırılması gerekir. ÖKT, yöneticilerin işletmeye dört önemli boyuttan bakmalarını sağlamaktadır. Bu dört boyut, bir işletmede ÖKT yapılandırılırken aşağıda belirtilen dört soru şeklinde dikkate alınmaktadır:

1. FINANSAL BOYUT:Pay sahiplerine nasıl görünmekteyiz?

2. MÜŞTERI BOYUTU:Müşteriler bize hangi göz ile bakmaktadır?

3. IÇSEL SÜREÇ BOYUTU:Mükemmelliği nasıl sağlayabiliriz?

4. ÖĞRENME VE GELIŞME BOYUTU:Gelişme ve değer yaratmayı nasıl devam ettirebiliriz?

Yapılandırılacak ÖKT'nin temel unsurlarını, bu sorulara işletme tarafından verilen cevaplar oluşturmaktadır. Üst düzey yöneticilere bu dört açıdan bilgi verildiğinde ÖKT, kullanılan ölçülerin sayısını azaltarak bilgi yükünü de azaltır. İşletmelerde ÖKT'nin yapılandırımasına geçmeden önce yönetsel gereklerin karşılanması gerekir (Kaplan ve Norton, 1992:73):Illk olarak;ÖKT, işletmenin rekabetçi yapısında yer alan (1)müşteri odaklı olma, (2)cevap sürelerinin kısaltılması, (3)takım çalışmasının öneminin vurgulanması, (4)kalitenin geliştirilmesi, (5)yeni mamulleri bulma süresinin kısaltılması ve (6)bunların uzun dönemde yönetilmesi gibi bir çok farklı unsuru tek bir yönetim raporu altında toplamaktadır. Ikinci olarak;ÖKT, ölçülerin eksik kullanımına karşı koymaktadır. Üst yöneticileri önemli operasyonel ölçüleri bir araya getirmeye zorlayarak, bir alanda yapılan harcamaların diğer alanlarda gelişme sağlayıp sağlamayacağının görülmesi konusunda da yöneticilere yardımcı olur.

Çok iyi yapılandırılmış bir ÖKT, işletmenin gelecekteki performansını etkileyen unsurların ölçümü ile geçmiş dönem performansının finansal ölçülerini bir araya getirmektedir. Bir işletmenin ÖKT'deki amaç ve ölçüleri, işletmenin strateji ve vizyonuna göre oluşturulmaktadır. İşletmeler, artık sadece maddi duran varlıklara yatırım yaparak sürdürülebilir bir rekabetçi avantaj elde edemeyecektir. Farklı bir şekilde ifade etmek gerekirse, işletmelerin "maddi olmayan duran varlıklar" ve "entelektüel sermayeye" yatırım yapması, devamlı bir rekabetçi avantajın sağlanması ve devam ettirilmesi açısından önemli bir "kritik faktör" haline gelmiştir. Dört boyutu ile ÖKT, işletmelere finansal sonuçların izlenmesi ile eş anlı olarak gelecekte "işletmenin 
gelişmesi" ve "rekabetçi güç" olma konusunda gerekli olan maddi olmayan duran varlıklara yapılan yatırımların kontrol edilmesi konusunda yardımcı olmaktadır (Sim ve Koh, 2001:19).

\subsubsection{Finansal Boyut}

Finansal boyut, işletme pay sahiplerine nasıl görünmektedir ve finansal olarak nasıl başarılı olunacaktır soruları ile şekillenmektedir. Finansal boyut, diğer boyutlardaki amaç ve ölçülere odaklanmaya yönelik hizmet vermektedir. Bu bakış açısı, kısa ve uzun dönemli finansal performansı geliştirmede en son noktaya gelen neden-sonuç ilişkilerinin bir parçası olan her faaliyetin kar amaçlı işletmelerdeki önemini yansıtır. Amaç ve ölçülerin tanımlanması sürecinde, farklı bölümler için farklı finansal ölçüler olabilir. Ancak, bu bölümlerdeki finansal amaçların işletme stratejisi ile uyumlu olması gerekir (Choe, Haddad ve Wilson, 1997:22)

Geçmişte yapılan işlerin ve bu olaylar ile ilgili mevcut durumun ölçülebilen sonuçlarını özetlemede finansal ölçüler çok yararlı olmaktadır. Bu nedenle ÖKT, finansal boyutu olduğu gibi kullanmaya devam eder. Finansal performans ölçüleri, bir işletmenin stratejisinin ve bu stratejiye yönelik işlem ve uygulamaların işletmeyi geliştirmeye katkıda bulunup bulunmadığını ortaya çıkarır (Kaplan ve Norton, 1996a:47-48). Finansal boyutta yer alan amaçlar, diğer boyutların amaç ve ölçüleri için odak noktası niteliğindedir. Seçilen her ölçünün, finansal performansta bir gelişmeye neden olacak neden-sonuç ilişkilerinin bir parçası olması gerekir. Diğer bir ifade ile, finansal boyut dışındaki üç boyuttaki gelişmelerin finansal performans üzerindeki etkisi açık bir şekilde ortaya konulmalıdır. Finansal boyutta yer alan performans ölçüleri, uzun dönemli amaçları tanımlamakta kullanılmaktadırlar. Finansal boyutta yer alan amaçlar, mamulün hayat döngüsündeki bölümlere göre belirlenir. Bu açıdan üç aşamaya göre farklı stratejiler belirlenebilir. Bu aşamalar, (1)Hızlı gelişme aşaması, (2)Devam aşaması ve (3)Son aşama, nakit giriş aşaması olarak belirlenmektedir (Kaplan ve Norton, 1996b:56-58).

Hızlı gelişen işletmeler, hayat döngülerinin ilk aşamasındadırlar. $\mathrm{Bu}$ işletmeler, yeni mamul/hizmet geliştirmek ve artırmak, üretim tesislerin yapılandırmak ve genişletmek, işlem kapasitesini artırmak, global ilişkileri destekleyecek sistem, yapı ve dağıtım ağlarına yatırım yapmak ve müşteri ilişkilerini geliştirmek için mantıklı yatırımlar 
yapacaklardır. Devam aşamasında yer alan işletmeler için yeni yatırımlar cazip haldedir. Ancak, yatırımın getirisinin çok yüksek ve hızlı dönüş özelliğine sahip olması gerekir. Bu aşamada, işletmelerden pazar payını koruyacağı ve muhtemelen bu payı yıldan yıla çok az geliştireceği beklenir. Yatırım projelerinin konusu, kapasiteyi genişletici, darboğazları aşmaya yönelik ve sürekli gelişmeyi devam ettirici yatırımlardır. Bu döngünün son aşamasında ise işletmeler, ilk iki aşamada yaptıkları yatırımın getirilerini beklemektedirler. Bu işletmeler, artık teçhizat ve kapasitenin devamlılığı dışında mevcut kapasitenin geliştirilmesi veya yeni kapasiteye yönelik önemli yatırımları taahhüt edemez. Esas amaç, nakit girişlerinde artışı sağlamaktır.

$\mathrm{Bu}$ üç aşamada finansal amaçlar, işletme için oldukça farklıdır.(1)Illk aşamada finansal amaçlar, satışlardaki artış, yeni müşteri ve pazarlara satış, yeni mamul/hizmetlerin satışı, mamul ve süreç geliştirmedeki harcama düzeyi ve yeni pazarlama, satış ve dağıtım kanallarının oluşturulması şeklinde sınıflandırılabilir.(2)ikinci aşamadaki finansal amaçlar arasında varlık devir hızı, faaliyet gelirleri ve brüt kar gibi klasik ölçüler yer alacaktır. (3)Son aşamada finansal amaçlar, nakit girişini vurgulamaktadır. Amaç, yatırımın getirisini artırmak değildir. Son aşamada kapasite artırıcı harcama yapılmaz. Finansal boyut, ÖKT' de diğer boyutlar ve işletme stratejisi ile ilişkili gösterilmelidir. Bu boyutta yer alan amaç ve ölçüler Tablo 1. üzerinde gösterilmektedir.

Tablo 1. Ölçüm Kartı Tekniğinde Finansal Boyut

\begin{tabular}{|l|l|}
\hline \multicolumn{2}{|c|}{ FINANSAL BOYUT } \\
\hline AMAÇLAR & ÖLÇÜLER \\
\hline Satışlar & Satış ve karlardaki yıllık artış \\
\hline $\begin{array}{l}\text { Yeni mamullerin sayısındaki } \\
\text { artış }\end{array}$ & Yeni mamullerin satış yüzdesi \\
\hline $\begin{array}{l}\text { Yeni bir fiyatlama stratejisinin } \\
\text { uygulanması }\end{array}$ & Mamul ve müşteri karlıı̆̆ı \\
\hline $\begin{array}{l}\text { Birim mamul maliyetinin } \\
\text { azaltılması }\end{array}$ & Mamullerin birim maliyeti \\
\hline $\begin{array}{l}\text { Birim müşteri maliyetinin } \\
\text { azaltılması }\end{array}$ & Müşterilerin birim maliyeti \\
\hline Satışların maliyeti & $\begin{array}{l}\text { Yıl bazında belli bir düzeyde kalma veya } \\
\text { azalma }\end{array}$ \\
\hline Varlık kullanımının geliştirilmesi & $\begin{array}{l}\text { Varlık sermayesi devir hızı } \\
\text { Ekonomik katma değer }\end{array}$ \\
\hline
\end{tabular}




\subsubsection{Müşteri Boyutu}

Müşteri boyutu, işletmenin vizyonuna ulaşması için müşterilere nasıl görünmelidir sorusu ile şekillenmektedir. Bir çok işletme günümüzde müşterilere odaklanmayı amaç olarak edinmiştir. Müşterilere "değer sunma" konusunda bir numara olmak, işletme amacının tipik bir ifadesidir. Bu nedenle, müşteriler için bir işletmenin nasıl faaliyette bulunacağı üst yönetim için öncelikli bir konudur (Kaplan ve Norton, 1992:73). Bugünkü anlayış, müşterilerin işletme maliyetlerini karşıladıkları ve karın elde edilmesine neden oldukları için, müşterilerin intiyaç ve isteklerine yönelmeleri doğrultusundadır. İşletmeler, rekabet edecekleri pazar ve müşteri bölümlerini seçmelidirler. Müşteri boyutu, müşteri değerleri ile ilgili (1)Müşteri tatmini, (2)Müşteri sadakati, (3)Müşterinin elde tutulması ve (4)Müşteri karlılığı ve (5)Pazar payı gibi ölçülerin, hedeflenen pazar ve müşteri bölümleri ile uyumlaştırılması konusunda işletmeye yardımcı olmaktadır (Hornsby ve Baxendale, 2001:35). Müşteri boyutu, çok iyi oluşturulmuş ve uygulanmış stratejinin başarılı sonuçlarını içerir. Genel sonuçlar içinde hedeflenen pazar bölümlerinde pazar payı, müşteriyi elde tutma, müşteri kazanma, müşteri tatmini ve müşteri karlıı̆ı gibi ölçüler yer almaktadır. Bu ölçüler, tüm işletme için genel ölçüler gibi görünmesine rağmen, işletmelerin gelişme ve karlılık beklediği hedef müşteri grupları ile de ilişkilendirilebilir (Kaplan ve Norton, 1996b:58).

Yöneticiler, müşteri tatmin ve memnuniyetini amaç olarak belirlemeden önce, işletmenin amaç ve stratejisini ÖKT'nin müşteri boyutunda pazar ve müşterilere özel hedefler haline dönüştürmelidir. Hedef olarak belirlenen bölümlere sunulacak "değer önerilerini" belirlemek, ÖKT'nin müşteri boyutunun amaç ve ölçülerini geliştirmeyi sağlayacak anahtardır. Böylece, işletmenin amaç ve stratejisi, ÖKT'nin müşteri boyutu ile hedef pazar ve müşteri düzeyinde özel amaçlara dönüştürülür (Kaplan ve Norton, 1996a:63-65). Unutulmamalıdır ki, eğer işletme uzun dönemde çok iyi bir finansal performansa ulaşmak istiyorsa, müşterilere "değer sunmanın" gereklerini en iyi şekilde yerine getirmelidir. ÖKT'de müşteri boyutunda yer alan genel ölçülere ilişkin açıklamalar aşağıda yapılmaktadır (Kaplan ve Norton, 1996b:59-61): 
i.Pazar payı: Hedeflenen müşteri bölümleri için pazar payı, bir işletmenin arzu edilen pazara nasıl en iyi şekilde gireceğini gösterir. Pazar payı, (1)müşteri sayısı, (2)toplam harcama miktarı veya (3)satılan mal miktarı gibi ölçüler ile işletmenin belirli bir pazarda yaptığı satışların ilgili pazardaki toplam iş hacmine oranını ifade etmektedir.

ii.Müşteriyi elde tutma: Hedeflenen müşteri gruplarında pazar payını korumanın ve artırmanın mantıklı bir yöntemi, mevcut müşterileri elde tutmadır. İşletmenin müşterileri ile sürdürdüğü ve koruduğu ilişkilerin oranını izleyen bir ölçüdür. Müşterilerin elde tutulmasında müşteri karlılığı gibi kıstasın esas alınması gerekir. $\mathrm{Bu}$ aşamada, müşteriyi elde tutmak, yeni müşteri kazanmaya göre daha dikkatli olmayı gerektirecektir (Ward, 1992:120)

iii.Müşteri kazanma: İşletmenin büyümesini sağlamak için genelde, hedeflenen bölümlerde müşteri tabanlı artış sağlamak amaç edilir. Müşteri kazanma, yeni müşterilerin sayısı ya da ilgili bölümde yeni müşterilere yapılan satış ile ölçülebilir. Müşteri kazanmanın işletmeye maliyeti, bunun için gereken yatırımlar ve yatırımların avantaj-dezavantajları dikkate alınarak incelenmelidir.

iv.Müşteri tatmini: Hem müşterinin elde tutulması hem de yeni müşterilerin kazanılması, müşterilerin ihtiyaçlarının karşılanması ile gerçekleştirilir. Müşteri tatmini ölçüleri, işletmenin işleri nasıl en iyi yaptığına ilişkin bir geri bildirim sağlar. Müşteriler, "karı gerçekleştiren taraflar" ve mamuller de "müşteri ihtiyaçlarını kara dönüştüren araçlardır". Tatmin olmuş bir müşteriye, işletme açısından mamulünü devamlı alacak gözü ile bakılmaktadır. Müşteri tatmini, müşteriyi elde tutma ve yeni müşteri kazanma için önemli bir belirleyicidir.

v.Müşteri karlılığı:Müşteriyi elde tutma, yeni müşteri kazanma ve müşteri tatminine yönelik olumlu gelişmeler, işletmenin karlı müşterilere sahip oldukları anlamına gelmez. Müşterileri tatmin etmeninin bir yolu, müşterilere düşük fiyatlardan mamul/hizmet sunmaktır. Müşteri tatmini ve yüksek pazar payı, yüksek finansal getirilire ulaşma araçları olduğundan, işletmeler, sadece müşterilere ne yaptıkları ile değerlendirme yapmayacak işletmenin karlılığı, hedeflenen müşteri bölümleri esas alınarak ölçülecektir. Müşteri karlıığı, tüm müşterilerin işletme için karlı 
olmadıklarını da ortaya çıkaracaktır. Bu tür durumlarda, karlı olmayan müşterilerden vazgeçilmesine ya da elde tutulmasına karar vermek için ömür boyu karlılık kıstası esas alınmalıdır. Yeni müşteriler, başlangıçta karsız olarak görülseler dahi gelecekteki potansiyelleri dikkate alınarak değerlendirilmelidir. $\mathrm{Bu}$ boyutta yer alan amaç ve ölçüler Tablo 2. üzerinde gösterilmektedir.

\section{Tablo 2. Ölçüm Kartı Tekniğinde Müşteri Boyutu}

\begin{tabular}{|l|l|}
\hline \multicolumn{2}{|c|}{ MÜŞTERI BOYUTU } \\
\hline AMAÇLAR & ÖLÇÜLER \\
\hline Pazar payının artması & Pazar payı yüzdesi \\
\hline $\begin{array}{l}\text { Müşteri sadakatinin } \\
\text { artırılması }\end{array}$ & $\begin{array}{l}\text { Gelişme yüzdesi, yeni müşteri/toplam } \\
\text { müşteri yüzdesindeki artış. }\end{array}$ \\
\hline $\begin{array}{l}\text { Devamlı, zamanlı } \\
\text { teslim }\end{array}$ & Siparişlerin karşılanması. \\
\hline $\begin{array}{l}\text { Karşılıklı ilişkilerin } \\
\text { geliştirilmesi }\end{array}$ & İlişkide bulunulan müşteri sayısı. \\
\hline $\begin{array}{l}\text { Müşteri tatmini } \\
\text { Mamul kalitesinin } \\
\text { artırılması }\end{array}$ & $\begin{array}{l}\text { Sıfır hata, tam zamanında teslim } \\
\text { yüksek kalite, düşük fiyat. }\end{array}$ \\
\hline Pazara girişlerde artış & Made yüzdesi \\
\hline
\end{tabular}

\subsection{3.İşletmenin İçsel Süreç Boyutu}

İçsel süreç ve geliştirme boyutu, mükemmelliği nasıl sağlayabiliriz sorusu ile şekillenmektedir. ÖKT'de yer alan bu boyutta yöneticiler, işletmedeki kritik içsel süreci tanımlamaktadırlar. Bir işletmenin pay sahiplerini ve müşterilerini tatmin edebilmesi için işletme sürecinde etkinlik nasıl sağlanmalıdır? Müşteri memnuniyetini sağlayacak faktörler tanımlandıktan sonra yönetim, müşterileri tatmin edebilmek için kritik içsel sürece odaklanmalıdır. Bu süreçlerde tam zamanında üretim, toplam kalite yönetimi, faaliyet tabanlı maliyetleme ve hedef maliyetleme gibi araç ve tekniklerin uygulanması yanı sıra etkinliğinin sağlanması ve geliştirilmesi gerekir (Tatikonda ve Tatikonda, 1998:51). Bu boyut, müşterilerin bugün ve gelecekteki ihtiyaçlarını tanımlanmasını ve bu ihtiyaçlara yönelik çözümlerin geliştirilmesini 
içeren bir iç değer zincirinin tanımlanmasının ötesine odaklanmaktadır. Bu boyut, mamul ve hizmetleri ile müşterilerine değer sunan tüm zinciri tanımladığından işletmenin kendisine özgü olacaktır (Choe, Haddad ve Wilson, 1997:23).

İçsel süreç boyutu, klasik ve ÖKT yaklaşımlarının performans ölçümüne yaklaşımları arasındaki iki temel farkı ortaya koymaktadır(Kaplan ve Norton, 1996a:92-94):ilk ayrım noktası, klasik yaklaşımlar, işletmedeki mevcut süreci kontrol ve geliştirmeye odaklanmaktadır. Her ne kadar kalite ve zaman gibi finansal olmayan ölçüler kullanılsa da bu yaklaşım halen mevcut sürece odaklanmaktadır. Ancak ÖKT, müşteri beklentileri ve finansal amaçlarda beklentileri karşılayacak yeni süreçleri tanımlamaktadır. İçsel süreç amaçları, işletmenin stratejisinde başarıya ulaşmasında çok önemli olan süreci vurgular. İkinci ayırım noktası, ÖKT'nin yenilik sürecini içsel süreç boyutuna dahil etmesidir. Klasik performans ölçüm sistemi, mevcut müşterilere yönelik mamul/hizmet sunumuna odaklanmaktadır. Ancak, uzun dönemli finansal başarının belirleyicileri, işletmenin mevcut ve gelecekteki müşterilerin intiyaçlarını karşılayacak yeni mamul/hizmetler geliştirmesinin gerekliliğini belirtir. İçsel sürecin işleyişi, Şekil 1. üzerinde gösterilmektedir.

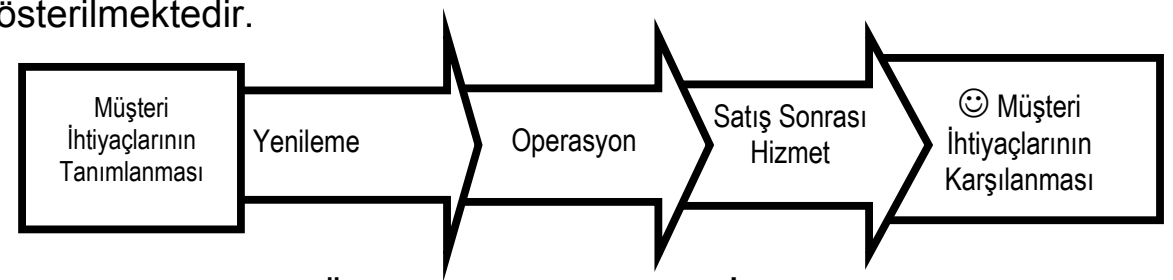

Şekil 1.Ölçüm Kartı Tekniğinde İçsel Süreç

Her işletme, müşterileri için değer yaratmak ve olumlu finansal sonuçlar elde edebilmek için bir dizi farklı işlem uygulayacaktır. Yukarıdaki şekilde ÖKT'nin içsel süreci gösterilmektedir. İşletmenin iç değer zincirinde, ÖKT açısından üç temel işlem yer almaktadır: (1)Yenileme, (2)Operasyon ve (3)Satış sonrası hizmetler. Bu üç sürecin başlangıç noktası, müşteri ihtiyaçlarının tanımlanması ve bitiş noktası ise, müşteri ihtiyaçlarının karşılanmasıdır. Yenileme sürecinde, müşterilerin yeni gelişen ve daha ortaya çıkmamış ihtiyaçlarının araştırılıp bu ihtiyaçları karşılayacak mamul/hizmetlerin tasarımı yapılır. Operasyon sürecinde ise, mevcut mamul ve hizmetler üretilip müşterilere sunulmaktadır. Bu aşamada, gerçekleştirilen faaliyetler ve mevcut mamullerde maliyet kontrolü ve maliyetlerin azaltılması önemli bir ağırlığa sahiptir. Satış sonrası hizmet sürecinde ise, işletmelerin 
mamul/hizmetleri müşteriye sunduktan sonra gerçekleştirdiği faaliyetler yer almaktadır.

Müşteri amaçlarının belirlenmesi ve bunların karşılanması, ÖKT'de finansal ve müşteri boyutları ile değerlendirilecektir. Bu boyutta yer alan amaç ve ölçüler Tablo 3. üzerinde gösterilmektedir.

Tablo 3. ÖIçüm Kartı Tekniğinde İçsel Süreç Boyutu IÇSEL SÜREÇ BOYUTU

\begin{tabular}{l|l|}
\hline AMAÇLAR & ÖLÇÜLER \\
\hline Yeni mamul sayısındaki artış & Yeni mamul sayısı/Planlanan yeni mamul \\
\hline Süreç kalitesinin artıııması & Kalite maliyetleri, hatalı mamul yüzdesi \\
\hline Süreç zamanın azaltılması & Üretim süreç etkinliği \\
\hline Süreç geliştirme & Hata oranında azalma, katma değer analizi \\
\hline Yeni mamule başlama & $\begin{array}{l}\text { Yeni mamul satışları, yeni mamule talep } \\
\text { sayısı }\end{array}$ \\
\hline İş gören tatmini & İş gören anketleri \\
\hline
\end{tabular}

\subsection{4.Öğrenme ve Gelişme Boyutu}

Öğrenme ve gelişme boyutu, işletmelerin vizyonuna ulaşabilmeleri için, öğrenme ve gelişme yeteneklerini nasıl devam ettirebilecekleri ve geliştirecekleri sorusu ile şekillenmektedir. Diğer bir ifade ile işletmeler, müşteriler için "değer yaratma" ve "değer sunma" konularında devamlılığı garanti edecekler mi? Müşteri ve içsel süreç, işletmeye hangi alanlarla ilgileneceği hakkında bilgi vermektedir. Ancak, müşteri tatmini değişme gösteren bir hedeftir. Bu hedefe ayak uydurabilmek için işletmeler, mevcut mamul ve üretim süreçlerinde devamlı gelişme sağlamalı, öğrenme ve yenilik yeteneklerini geliştirmeli ve sürdürmelidir (Tatikonda ve Tatikonda, 1998:51). Değişen başarı hedefleri ve artan rekabet, işletmelerin mevcut mamul ve süreçleri için devamlı geliştirme faaliyetinde bulunmalarını gerektirmektedir. Bir işletmenin yenilik, geliştirme ve öğrenme yeterliliği doğrudan işletmenin değerini düzenlemektedir (Kaplan ve Norton, 1992:76)

$\mathrm{Bu}$ boyut, işletmenin uzun dönemli gelişme ve ilerleme elde edebilmesi için gerekli olan yapıyı tanımlar. Müşteri ve içsel süreç boyutları, mevcut ve geleceğe ilişkin başarı için çok kritik olan faktörleri tanımlar. İşletmeler, muhtemelen bugünün teknoloji ve kapasitesini kullanarak müşteri ve içsel süreç için uzun dönemli hedefleri 
karşılayamayacaklardır (Kaplan ve Norton, 1993:63-64). Bu boyut, işletmeye gelecek için hazırlıklı olma konusunda yardımcı olmaktadır. Öğrenme ve gelişme boyutunda yer alan amaçlar, diğer üç boyutta belirlenen hedeflerin gerçekleştirilmesi için gerekli alt yapıyı sağlar. Kısa dönemli finansal performansa dayalı değerlendirmeler yapıldığında çalışanlar, sistem ve kurumsal yapının geliştirilmesi için yapılacak yatıımların zor olduğu belirtilmektedir. Finansal muhasebe anlayışında, bu tür yatırım için yapılan harcamalar dönemsellik gereği dönemler ile ilişkilendirilmekte ve bu harcamalar azaltılınca dönemin gelirinde artış sağlanmaktadır. Ancak, çalışanlar, sistem ve kurumsal yapıya yönelik yapılan yatırımlardaki yetersizlik, kısa dönemde etkisini göstermeyecektir. Bu nedenledir ki işletmelerde, geleceğe yönelik olarak bu boyut incelenirken üç temel unsur esas alınmaktadır (Kaplan ve Norton, 1996a:127):(1)Çalışanlar (2)Organizasyonel süreç ve (3)Sistemler.

ÖKT'deki finansal, müşteri ve içsel süreç amaçları çalışan, sistem ve organizasyonel sürecin mevcut yeterlilikleri ve ileri düzeyde performansa ulaşmak için ne yapılması gerektiği arasındaki açığı en iyi şekilde ortaya koymaktadır. Bu açığı kapatmak için işletmeler, çalışanların uzmanlık kazanması, yönetim bilgi sistemleri ve teknolojisinin güncelleştirilmesi ve organizasyonel süreç ve işlemlerin uyumlaştırılması için yatırım yapacaklardır (Kaplan ve Norton, 1993:64). Bu boyutta yer alan amaç ve ölçüler Tablo 4. üzerinde gösterilmektedir.

\section{Tablo 4. Ölçüm Kartı Tekniğinde Öğrenme ve Gelişme Boyutu}

\begin{tabular}{|l|l|}
\hline \multicolumn{2}{|c|}{ ÖĞRENME VE GELIŞME BOYUTU } \\
\hline \multicolumn{1}{|c|}{ AMAÇLAR } & \multicolumn{1}{c|}{ ÖLÇÜLER } \\
\hline Yeni mamul liderliği & $\begin{array}{l}\text { Yeni mamullerden elde edilen satışlar, } \\
\text { Ar\&Ge harcamaları, tasarım } \\
\text { maliyetlerinin toplam maliyet içindeki } \\
\text { payı }\end{array}$ \\
\hline $\begin{array}{l}\text { Çalışanların } \\
\text { yeteneklerinin } \\
\text { geliştirilmesi }\end{array}$ & $\begin{array}{l}\text { Çalışan tatmini } \\
\text { Çalışan devir hzı }\end{array}$ \\
\hline $\begin{array}{l}\text { Çalışanlar } \\
\text { motivasyonu }\end{array}$ & Çalışanların dönemlik incelenmesi \\
\hline Beklenti üstü gelişme & Yeni mamullerden edinilen satışlar \\
\hline Teknoloji liderliği & Yeni mamulleri geliştirme süresi \\
\hline
\end{tabular}




\section{2.Ölçüm Kartı Tekniğinin İşleyişi}

ÖKT, işletme yöneticilerine performans ölçümüne farklı bir açıdan bakma konusunda yardımcı olmaktadır. Belirlenen dört farklı ÖKT boyutu, farklı ortamlardaki değişikliklere uyma konusunda işletmelere yardımcı olurken rekabetçi pazarlarda önemli bir avantajın da elde edilmesini sağlamaktadır. ÖKT'de yer alan bu dört boyut ve her biri içinde yer alan amaçlar ve ölçüler birbiri ile ilişki içindedir. Amaç, işletmenin başarısı olduğundan her bir boyut ÖKT ile işletmenin maliyet yönetim sistemleri, üretim sistemleri, yönetim anlayışı kısaca işletmenin her fonksiyonu ile ilişkili olacaktır.

ÖKT kullanılan işletmelerde, kısa dönemli finansal ölçülere bakılarak finansal performansın değerlendirilmesi hatalı sonuçlar verebilir. Bu nedenle ÖKT, yöneticileri uzun dönemli stratejik amaçları kısa dönemli işlemlerle ilişkilendiren dört yeni yönetim sürecine sokmaktadır (Kaplan ve Norton, 1996c:75-76). İlk süreçte, vizyonun aktarılması gerçekleştirilir. Bu süreç, yöneticilere işletmenin vizyon ve stratejisi etrafında yeni bir anlayış oluşturmaları konusunda yardımcı olur ve stratejinin operasyonel ifadeler ile tanımlanması sağlanır.

İkinci süreç, iletişim ve bağlantı kurmadır. Bu süreç, yöneticilere, stratejinin tüm organizasyonel basamaklara yayılması ve bölüm amaçları ile ilişkisinin kurulmasında yardımcı olur. ÖKT, yöneticilere tüm basamaklarda uzun dönemli stratejinin anlaşılması ve bu stratejinin bölüm bazında amaçlar ile ilişkilendirilmesi konusunda yardımcı olmaktadır .Üçüncü süreç, işletmede planlamadır. Bu süreç, işletme ve finansal planların birleştirilmesine yardımcı olur. Dördüncü süreç ise, öğrenme ve geri beslemedir. Bu süreç, işletmeler için stratejik öğrenme yeteneklerini belirlemede yardımcı olur. Mevcut geri besleme ve inceleme anlayışı bütçelenen finansal amaçların karşılanmasına odaklanırken ÖKT, müşteri, içsel süreç ve öğrenme ve gelişme boyutları ile kısa vadeli sonuçları değerlendirmektedir.

ÖKT, işletme içindeki bir gelişme ve ilerlemenin finansal sonuçlara dönüşümünü sağlamakla birlikte stratejilerin de etkin bir şekilde kontrolünü de sağlamaktadır. Bu nedenle ÖKT, organizasyonun her aşamasında gerçekleştirilen faaliyetlerin işletme stratejisi ile uyumlu olup olmadığının belirlenmesi konusunda yönetime yardımcı olmaktadır. Her boyutta yer alan amaçlar ve ölçüler, işletme stratejisi ve 
amaçları ile ters düşmemelidir. Her boyutun işletme stratejisi ve birbiri arasındaki ilişikler Şekil 2. üzerinde gösterilmektedir.

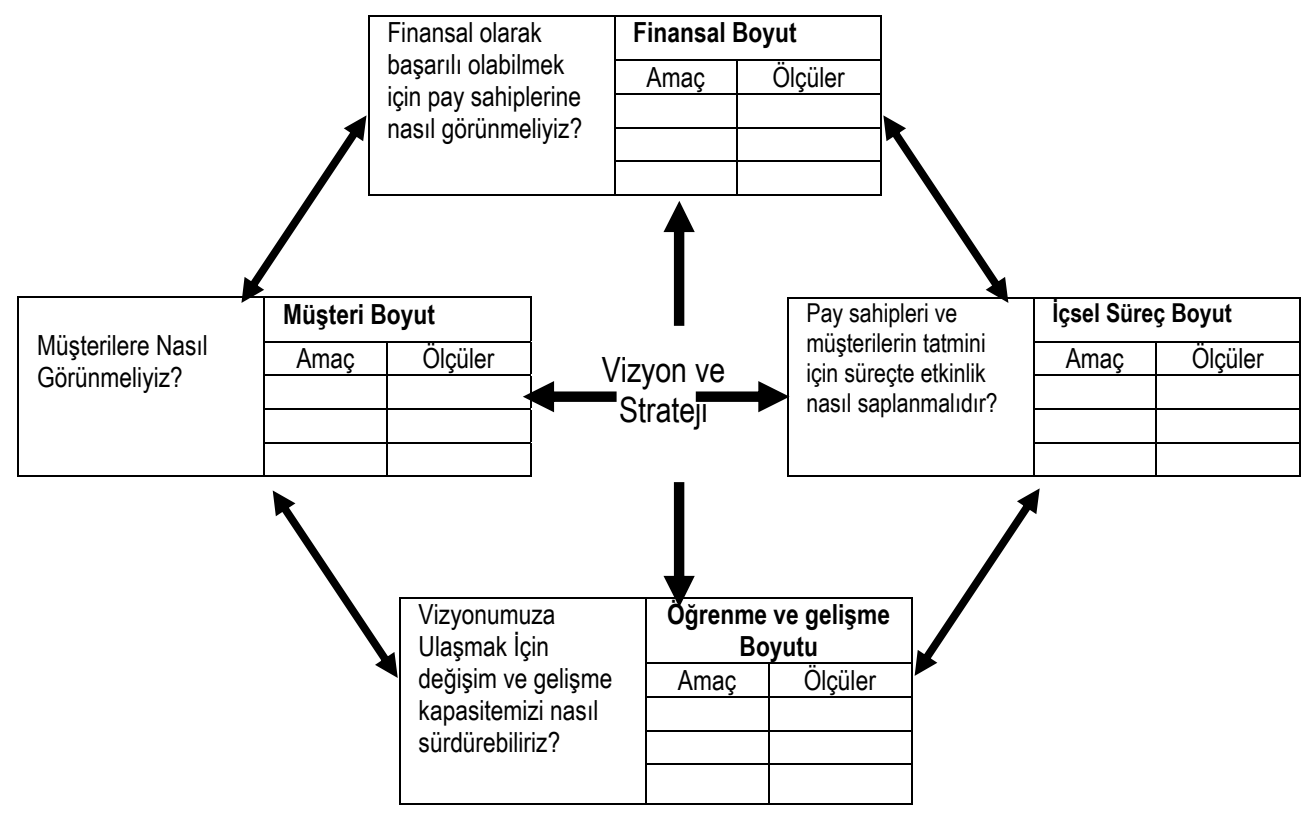

\section{Şekil 2.ÖIçüm Kartı Tekniği'nin Strateji ile İlişkisi}

Kaynak:KAPLAN ve NORTON, “Using the....", agk., s76.

ÖKT uygulamalarında başarılı olmak için işletmeler, aşağıdaki hususları dikkate almalıdırlar (McCunn, 1998:34-35):

- ÖKT'yi stratejik amaçlara ulaşmada bir yol olarak kullanmak:Stratejik amaçların işletmenin her kesimine aktarılmasında ÖKT'nin etkin bir araç olarak kullanılması.

- ÖKT uygulanmadan önce stratejik amaçları belirlemek:Stratejik amaçlar belirlenmeden ÖKT'nin uygulanması hatalı sonuçlar doğuracaktır.

- ÖKT uygulamalarında güçlü bir tepe yönetimi desteği bulmak ve ilgili yöneticileri inandırmak:Sorumluluğu yönetim muhasebesine bırakmadan işletmede her kesimin projeye etkin bir şekilde katılımını sağlamak. 
- Genel uygulamaya geçmeden önce pilot uygulamayı yapmak.

- ÖKT'nin uygulanmasından önce işletmede her birim için sorumluluk belirlemek.

- ÖKT' yi yukarıdan aşağı kontrol aracı olarak kullanmamak:Bu durum çalışanlar için isyan nedeni olacaktır.

- ÖKT projesini standart hale getirmemek:ÖKT, ihtiyaca göre değiştirilen esnek bir yapıya sahip olmalıdır.

- ÖKT'nin kullanımında eğitim ve iletişim gereklerini göz önünde tutmak.

- Mükemmellik için karışıklığa neden olmamak.

- Yönetimin ek iş yükünü ve ÖKT uygulamalarının maliyeti dikkate almak.

- Neye ulaşmak istediğini bilmeden ÖKT'yi uygulamamak.

\section{SONUÇ}

Ölçüm kartı tekniği ve işletme stratejisi ile ortaya konan ilişkiler, işletmenin diğer sistemleri için de geçerlidir. Bir işletmenin stratejik planının başarıı bir şekilde uygulanmasındaki anahtar faktör, performans ölçümüdür. Performans ölçüm sistemi, planlama sürecinde geliştirilen amaç ve hedefler ile ilgili olarak işletmelerin amaç ve hedeflere ulaşma derecesini ölçer. Sadece üretimdeki gelişmeler değil, işletmenin faaliyet gösterdiği ortamdaki tüm hareket tarzları ölçüme tabi tutulur. İşletmenin nihai amacı olan finansal mükemmelliğe ulaşması için oluşturulan stratejinin, üst yönetimin sınırları dahilinde kalmaması ve organizasyonun alt basamaklarına da aktarıması gerekir. Kısaca, amaçlara ulaşmak için strateji ile ortaya konan amaçların sadece üst yönetim tarafından değil, işletmedeki her çalışanın katııımı ile belirlenmesi, hem belirlenen stratejik amaçların anlaşılması hem de çalışanların bu amaçlara inanması açısından oldukça önemlidir. Finansal performans, müşteri tatmininden etkilenmektedir. Bu etkilenme sırası ile işletmenin değer zincirinde etkisini gösterecektir. Üretim ortamındaki yenilik ve gelişmelerin de etkisi, müşteri tatmini üzerinde etkisi olacaktır. Bu zincirde, neden-sonuç bağlantısı stratejilerin uygulanması ve değerlendirilmesinde güçlü bir araçtır. Bu bağlantı, ölçüm kartı tekniği ile sağlanmaktadır. ÖKT, yeni performans ölçülerinin tanımlanmasını kolaylaştırmaktadır. İşletmeler, strateji haritaları ve ÖKT' yi kullandıkları zaman yeni performans ölçüleri ve neden-sonuç bağlantıları ortaya çıkmaktadır. Kısaca, strateji ve 
stratejinin uygulaması arasında bağı oluşturan, stratejiyi işletmede her kesimin bir işi haline getiren bir anlayış olan ölçüm kartı tekniği, işletmenin dününün değerlendirilmesi değil, geleceğinin şekillendirilmesi konusunda yönetime yardımcı olan bir yönetim muhasebesi aracıdır. 


\section{KAYNAKLAR}

1. BEISCHEL, Mark E. ve SMITH, Richard K., (1991), "Linking the Shop Floor To The Top Floor", Management Accounting, October.

2. BERLINER, Callie ve BRIMSON, James A., (1988), "Cost management for Today's Advanced Manufacturing:CAM-I Conceptual Design", CAM-I, U.S.A.

3. BLOCHER, Edward, CHEN, Kung H. ve LIN, W.Thomas, (2001), "Cost Managemnet:A Strategic Emphasis", McGraw-Hill.

4. BLOCHER, Edward, CHEN, Kung, COKINS, Gary ve LIN, Thomas, (2005), "Cost Manage-ment:A Strategic Emphasis", 3/e, McGrawHill.

5. CHOE, Chee W., HADDAD, Kamal H. ve WILSON, James E., (1997), "Appling the Balanced Scorecard to Small Companies", Management Accounting, August.

6. CONSTANTINIDES, Kim ve SHANK, John K., (1994), "Matching Accounting to Strategy: One Mill's Experience", Management Accounting, September.

7. EPSTEIN, Marc J. ve MANZONI, Jean-François, (1997), "Translating Strategy Into Action", Management Accounting, August.

8. FRIGO, Mark L., (2002), "Strategy and Balanced Scorecard", Strategic Finance, November, .

9. GLAD, Ernest ve BECKER, Hugh, (1995), "Activity-Based Costing And Management", John-Willey\& Sons, U.S.A.

10. HORNSBY, Donavan D. ve BAXENDALE, Sidney, (2001), "Building A Balanced Scorecard For Enterpreneurs", Journal of Cost Management, November/ December.

11. HOWELL, Robert A., BROWN, James D., S.R.SOURCY ve A.H.SEED, (1987), “Management Accounting In the Manufacturing Environment Current Cost Management Practice In Automated Manufacturing Environments", National Assocation of Accountants,

12. KAPLAN, Robert S. ve NORTON, David P., (1992), "The Balanced Scorecard-Measures That Drive Performance"Harvard Business Review, January-February.

13. KAPLAN, Robert S. ve NORTON, David P, (1993), "Putting the Balanced Scorecard to Work", Harvard Business Review, September-October.

14. KAPLAN, Robert S. ve NORTON, David P., (1996a), "The Balanced Scorecard: Translating Strategy Into Action", Harvard Business School Press, U.S.A.

15. KAPLAN, Robert S. ve NORTON, David P., (1996b), "Linking the Balanced Scorecard to Strategy", California Management Review, Sayı 39, No1, Fall.

16. KAPLAN, Robert S. ve NORTON, David P., (1996c), "Using the Balanced Scorecard as a Strategic Management System", Harvard Business Review, January-February. 
17. KEEGAN, Danel P., EILER, Robert G. ve JONES, Charles R., (1989), "Are Your Performance Measures Absolote?", Management Accounting, June.

18. McCUNN, Paul, (1998), "The Balanced Scorecard, the Eleventh Commandment", Management Accounting, December.

19. McNAIR, C.J., LYNCH, Richard L. ve CROSS, Kelvin F., (1990), "Do Financial and Nonfinancial Performance Measure Have to Agree?"Management Accounting, November.

20. SANTORI, Peter R. ve ANDERSON, Alan D., (1987), "Manufacturing Performance in the 1990s: Measuring for Excellence", Journal of Accountancy, November.

21. SILK, Scott, (1998), "Automating the Balanced Scorecard", Management Accounting, May

22. SIM, Khim L. ve KOH, Hian C., (2001), "Balanced Scorecard:A Rising Trend In Strategic Performance Measurement", Measuring Business Excellence.

23. SMITH, Malcolm, (1995), "New Tools for Management Accounting Putting Activity Based Costing and Non-Financial Indicators to Work", Pitman Publishing, U.K.

24. TATIKONDA, Lakshmi U. ve TATIKONDA, Rao J., (1998), "We Need Dynamic Performance Measures", Management Accounting, September.

25. WAAL, Andre A De, (2003), "The Future of The Balanced Scorecard:An Interview with Professor Dr. Robert S.KAPLAN", Measuring Business Excellence, Vol, 7, No.1.

26. WARD, Keith, (1992), "Strategic Management Accounting", Butterworth-Heinemann, 